\title{
PENINGKATAN NILAI NUTRISI DEDAK PADI SEBAGAI PAKAN ITIK MELALUI BIOFERMENTASI DENGAN KHAMIR
}

\author{
WIBAWA A.A.P., WIRAWAN I W., DAN PARTAMA I. B. G \\ Program Studi Peternakan, Fakultas Peternakan, Universitas Udayana, Denpasar \\ E-mail: aputrawibawa@yahoo.com
}

\begin{abstract}
ABSTRAK
Penelitian ini bertujuan untuk mempelajari pengaruh penggunaan kultur khamir Saccharomyces spp kompleks sebagai inokulan fermentasi dedak padi terhadap kualitas dedak padi sebagai pakan itik. Rancangan yang dipergunakan dalam penelitian ini adalah rancangan acak lengkap (RAL) dengan tiga macam perlakuan dan enam kali ulangan. Ketiga perlakuan yang dicobakan, yaitu dedak padi tanpa terfermentasi sebagai kontrol (A); dedak padi terfermentasi dengan 0,20\% kultur khamir Saccharomyces spp kompleks (B), dan dedak padi terfermentasi dengan 0,40\% kultur khamir Saccharomyces spp kompleks (C). Hasil penelitian menunjukkan bahwa fermentasi dedak padi dengan 0,20\% dan 0,40\% kultur khamir Saccharomyces spp kompleks nyata $(\mathrm{P}<0,05)$ dapat meningkatkan kandungan protein kasar dan serat kasar dedak padi, serta secara nyata $(\mathrm{P}<0,05)$ dapat meningkatkan kecernaan bahan kering, bahan organic, protein, dan serat kasar dedak padi dibandingkan dengan kontrol. Fermentasi dedak padi dengan kultur khamir Saccharomyces spp kompleks ternyata tidak berpengaruh nyata $(\mathrm{P}>0,05)$ bahan kering, bahan organik, dan gross energi dedak padi. Akan tetapi, secara nyata $(\mathrm{P}<0,05)$ meningkatkan kandungan energi termetabolis dedak padi. Dari hasil penelitian ini dapat disimpulkan bahwa fermentasi dedak padi dengan 0,20-0,40\% kultur khamir Saccharomyces spp kompleks dapat meningkatkan kandungan nutrisi dan kecernaan dedak padi sebagai pakan itik.
\end{abstract}

Kata kunci: biofermentasi, Saccharomyces spp., dedak padi, kecernaan, serat kasar

\section{THE INCREASE OF RICE BRAN QUALITY BY KHAMIR BIOFERMENTATION AS FEEDING OF DUCKS}

\begin{abstract}
This research was carried out to study the increase of rice bran quality by complexs Saccharomyces spp culture fermentation as feeding of duck, at Tabanan, Bali. The research used a completely randomized design (CRD) with three treatments in six replicates. The third treatment were unfermented rice bran as control(A); fermented rice bran by $0.20 \%$ complexs Saccharomyces spp culture (B); and fermented rice bran by 0.20\% complexs Saccharomyces spp culture (C) repectively. The results of this experiment showed that fermentation rice bran with $0.20-0.40 \%$ complexs Saccharomyces spp culture increased significantly different $(\mathrm{P}<0.05)$ the crude protein and crude fibre of rice bran. Rice bran fermented by 0.20-0.40\% complexs Saccharomyces spp culture were increased significantly different $(\mathrm{P}<0.05)$ on dry matter digestibility, organic digestibility, protein, and crude fibre digestibility rather than control. Rice bran fermented by 0.20-0.40\% complexs Saccharomyces spp culture were not effect significantly different $(\mathrm{P}>0.05)$ on dry matter, organic matter, and gross energy of rice bran. But, was increased significantly different $(\mathrm{P}<0.05)$ on metabolizable energy of rice bran. It was concluded that fermentation of rice bran by complexs Saccharomyces spp culture were increased nutrient and digestibility of rice bran as duck feeding.
\end{abstract}

Kata kunci: biofermentation, Saccharomyces spp., rice bran, digestibility, crude fibre

\section{PENDAHULUAN}

Penggunaan dedak padi sebagai campuran pakan unggas memiliki konstribusi yang cukup besar, yaitu sekitar $25-30 \%$ dari seluruh komponen pakan itik. Hal ini disebabkan karena harga dedak relatif murah, tidak bersaing dengan manusia, dan jumlahnya melimpah pada saat musim panen padi (Rasyaf, 2002). Dinyatakan juga bahwa keterbatasan penggunaan dedak padi sebagai campuran pakan unggas adalah kandungan proteinnya yang rendah, mudah tengik, dan adanya asam fitat yang mampu mengikat mineral Ca dan $\mathrm{P}$, serta mengikat protein menjadi fitat-protein kompleks yang berdampak pada menurunnya manfaat serta kecernaannya. Oleh 
karena itu, ransum yang menggunakan komponen dedak padi yang cukup tinggi (20-30\%) perlu dilakukan rekayasa bioteknologi. Bioteknologi yang mudah dan murah untuk itu adalah bioteknologi fermentasi dengan memanfaatkan jasa mikroba yang juga nantinya dapat berfungsi sebagai probiotik di dalam saluran pencernaan itik.

Menurut Bidura (2007), keuntungan fermentasi oleh mikroba adalah mampu mengubah makro molekul protein menjadi mikro molekul yang mudah dicerna oleh unggas serta tidak menghasilkan senyawa kimia beracun. Dilaporkan juga, selain dapat meningkatkan kandungan protein dalam ransum, proses fermentasi juga dapat meningkatkan kecernaan pakan dan dapat melepas ikatan senyawa kompleks menjadi senyawa yang mudah dicerna.

Khamir fermentasi yang menarik untuk dicobakan untuk meningkatkan nilai guna dedak padi tersebut adalah khamir Saccharomyces spp yang diisolasi dari ragi tape. Beberapa peneliti melaporkan bahwa penggunaan khamir sebagai inokulan fermentasi nyata dapat meningkatkan kandungan protein pakan dan sebaliknya nyata menurunkan kandungan serat kasar pakan (Widiyazid et al., 2002). Hasil penelitian Londra (2007) melaporkan bahwa sampah pasar yang mengalami fermentasi ternyata kandungan proteinnya $62,69 \%$ nyata lebih tinggi daripada tanpa fermentasi, sebaliknya kandungan serat kasarnya menurun secara signifikan.

Widiyanto et al. (1994) melaporkan, pada saat difermentasi oleh khamir maka kandungan serat kasar ransum didegradasi oleh mikroba tersebut, sehingga dapat dimanfaatkan oleh ternak unggas. Khasiat lain dari produk pakan fermentasi seperti dilaporkan oleh Tanaka et al. (1992) bahwa penggunaan bahan pakan produk fermentasi ternyata dapat menekan aktivitas enzim 3-hydroxy-3-methylglutaryl Co-A reduktase yang berfungsi untuk mensintesis kolesterol dalam hati. Penggunaan produk fermentasi dalam ransum nyata menurunkan jumlah lemak tubuh ayam (Kataren et al., 1999).

Tujuan penelitian ini adalah untuk membuktikan bahwa penggunaan jasa khamir Saccharomyces spp yang diisolasi dari ragi tape sebagai inokulan fermentasi dedak padi dapat meningkatkan nilai nutrisi dedak padi, dilihat dari kandungan nutrisi dan kecernaannya pada itik Bali.

\section{MATERI DAN METODE}

\section{Lokasi dan Waktu Penelitian}

Penelitian lapangan di laksanakan di kandang milik petani peternak di Desa Dajan Peken, Kecamatan Tabanan, Kabupaten Tabanan, Bali. Analisis laboratorium dilaksanakan di Laboratorium Teknologi Hasil Ternak,
Fakultas Peternakan, dan Laboratorium Biosains, Universitas Udayana, serta Laboratorium Nutrisi, Fakultas Peternakan, Institut Pertanian Bogor, Bogor. Penelitian berlangsung selama tujuh bulan, yaitu mulai persiapan sampai dengan pengolahan data (Mei-Oktober 2014).

\section{Bahan Penelitian}

Materi yang digunakan adalah ragi tape berbagai merk yang umumnya digunakan dalam pembuatan tape. Pembuatan media kultur enrichment dan media selektif OMEA, serta identifikasi mikroba dilaksanakan di Lab. Teknologi Hasil Ternak, Fakultas Peternakan, Lab. Biosains Universitas Udayana, Denpasar. Peralatan yang digunakan dalam penelitian ini adalah inkubator, autoklaf, sentrifuge, magnetic stirrer, adiabatic oxygen bomb calorimeter, mikro pipet, pipet tetes, timbangan analitik, oven, desikator, refrigator, dan tabung reaksi.

\section{Itik dan Kandang}

Itik yang digunakan adalah itik bali jantan yang diperoleh dari petani peternak itik lokal di daerah Tabanan umur delapan minggu dengan berat badan homogen. Kandang dengan sistem battery individual dari bilah bambu sebanyak 6 buah. Tiap petak kandang berukuran panjang $0,50 \mathrm{~m}$, lebar $0,40 \mathrm{~m}$, dan tinggi o,40 m. Semua petak kandang terletak dalam sebuah bangunan kandang dengan atap genteng. Tiap petak kandang sudah dilengkapi dengan tempat pakan dan air minum.

\section{Fermentasi Dedak Padi}

Prosedur fermentasi dedak padi sebagai berikut:

1) dedak padi dikukus selama 45 menit dihitung sejak air kukusan mendidih, kemudian didinginkan;

2) Setelah dingin, selanjutnya ditambahkan kultur Saccharomyces spp terpilih sebanyak 0,20\% dari berat dedak padi yang akan difermentasi, kemudian disemprot dengan larutan gula $4 \%$ sambil diaduk secara merata,

3) selanjutnya dedak padi tersebut dimasukkan kedalam kantung polyetilene yang telah dilubangi dibeberapa tempat untuk mendapatkan kondisi aerob, selanjutnya diinkubasi pada suhu ruang selama 3 hari, selama inkubasi substrat dikondisikan pada ketebalan $2 \mathrm{~cm}$; dan

4) setelah masa inkubasi selesai, produk dikeringkan selama 24 jam pada suhu kamar, setelah kering kemudian digemburkan kembali dan siap dicampurkan dengan bahan pakan lainnya (Suprapti et al., 2008).

\section{Penentuan Kecernaan Pakan Dengan Metode "Force Feeding"}

Penentuan kecernaan dengan metode force feeding. 
Rancangan yang digunakan adalah rancangan acak lengkap (RAL) dengan 3 perlakuan dan 6 kali ulangan. Ketiga perlakuan tersebut adalah: dedak padi tanpa fermentasi sebagai control (A), dedak padi terfermentasi dengan 0,20\% kultur khamir Saccharomyces spp kompleks (B), dan dedak padi terfermentasi dengan 0,40\% kultur khamir Saccharomyces spp kompleks (C). Tiap ulangan menggunakan 1 ekor itik Bali jantan dewasa (individual cage).

Terlebih dahulu dipersiapkan masing-masing 6 ekor itik dewasa untuk setiap pakan (sebagai ulangan) yang akan dicobakan. Semua itik dipuasakan pakan (air minum tetap diberikan) selama 16 jam dan ditempatkan dalam kandang metabolis ("individual cage"). Selanjutnya dedak padi yang sudah dan belum mengalami fermentasi dimasukkan kedalam tembolok itik secara hati-hati dengan bantuan tangan dan slang air. Banyaknya pakan yang diberikan, terlebih dahulu ditimbang sebanyak 50 g. Lebih rinci tersaji pada Gambar 2.

Penentuan Kecernaan Pakan Dengan Metode "Force Feeding". Penentuan kecernaan dengan metode ini, terlebih dahulu dipersiapkan masing-masing 6 ekor itik dewasa untuk setiap pakan (sebagai ulangan) yang akan dicobakan. Semua itik dipuasakan pakan (air minum tetap diberikan) selama 16 jam dan ditempatkan dalam kandang metabolis ("individual cage"). Selanjutnya dedak padi yang sudah dan belum mengalami fermentasi dimasukkan kedalam tembolok itik secara hati-hati dengan bantuan tangan dan slang air (tersaji pada Gambar 2). Banyaknya pakan yang diberikan sebanyak $50 \mathrm{~g}$.

\section{Analisis Sampel Pakan (Dedak Padi) dan Ekskreta (Feses)}

Sampel pakan dan ekskreta (feses) selanjutnya dianalisis proksimat dengan metode AOAC (1994). Kandungan protein kasar ditentukan dengan metode Kjeldahl (AOAC, 1994). Sedangkan kandungan serat kasar ditentukan dengan metode Van Soest et al. (l991). Koefisien cerna yang diamati meliputi koefisien cerna bahan kering (KCBK) dan bahan organik (KCBO). Koefisien cerna zat makanan dapat dihitung dengan mengunakan rumus:

Koefisien cerna $=\underline{\text { Konsumsi ransum }- \text { jumlah ekskreta }} \times 100 \%$ ransum Konsumsi ransum

\section{Pengambilan Sampel Kotoran Itik}

Kotoran itik ditampung pada lembaran plastik yang ditempatkan di bawah kandang. Sampel kotoran yang didapat dikeringkan terlebih dahulu. Pengeringan dilakukan dengan menjemur kotoran di bawah sinar matahari dan dilakuan segera setelah kotoran basah

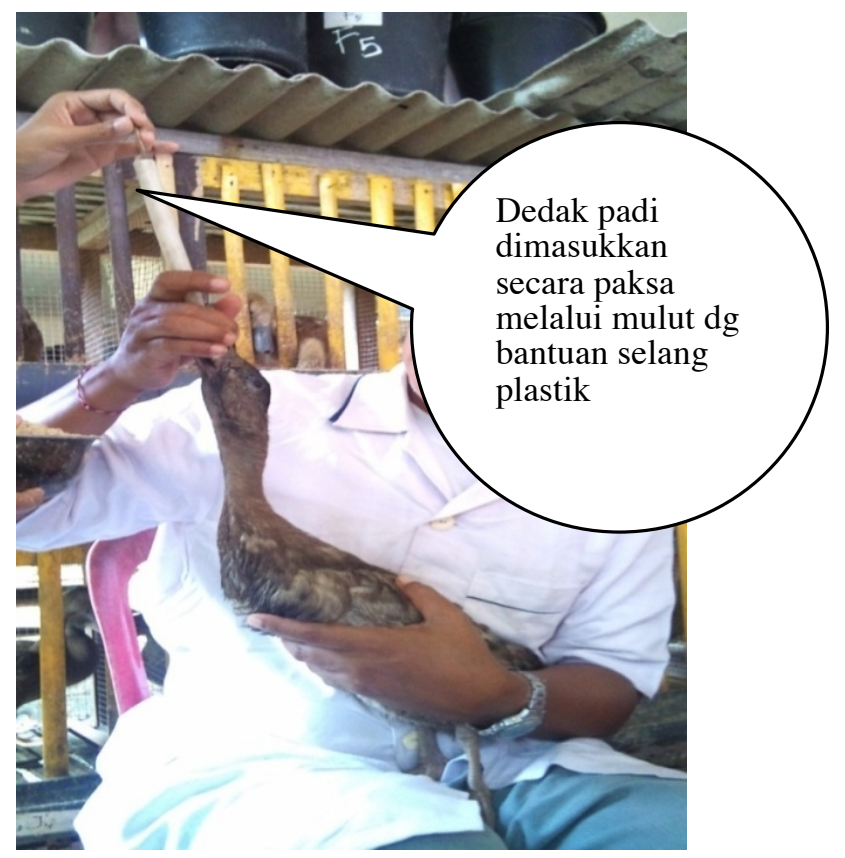

Gambar 1. Metode force-feeding untuk menentukan kecernaan dedak padi

ditimbang. Setelah kotoran kering, kotoran ditimbang lagi untuk mendapatkan berat kering matahari sesuai kode perlakuan dan ulangan. Kotoran yang sudah kering selanjtnya ditumbuk halus dibawa ke laboratorium untuk dianalisis.

Energi termetabolis pakan dihitung sebagai berikut ini:

Metabolizable energy $(M E)$ = energi yang dikonsumsi - energi ekskreta

Gross energi dihitung dengan menggunakan adiabatic oxygen bomb calorimeter.

\section{Analisis Statistika}

Data yang diperoleh di analisis dengan sidik ragam dan apabila terdapat perbedaan yang nyata $(\mathrm{P}<0,05)$ di antara perlakuan, maka dilanjutkan dengan uji jarak berganda dari Duncan (Steel dan Torrie, 1989).

\section{HASIL DAN PEMBAHASAN}

\section{Bahan Kering dan Bahan Organik}

Hasil analisis laboratorium menunjukkan bahwa kandungan bahan kering dedak padi kontrol (tidak mengalami fermentasi) adalah 88,97\% 10,93\% berat kering (Tabel 3). Kandungan bahan kering dedak padi yang mengalami fermentasi dengan kultur khamir Saccharomyces spp kompleks 0,20\% (B) dan kultur khamir Saccharomyces spp kompleks 0,40\% (C) tidak menunjukkan adanya perbedaan yang nyata $(\mathrm{P}>0,05)$ dibandingkan dengan kontrol (A). Kandungan bahan organik (BO) dedak padi kontrol adalah 89,85\% 10,93\% 
berat kering (Tabel 3). Biofermentasi dedak padi dengan menggunakan kultur khamir Saccharomyces spp kompleks ternyata tidak berpengaruh nyata $(\mathrm{P}>0,05)$ terhadap kandungan bahan organik dedak padi. Hasil penelitian menunjukkan bahwa biofermentasi dedak padi dengan menggunakan kultur khamir Saccharomyces spp kompleks (isolasi dari ragi tape) secara signifikan dapat meningkatkan nilai nutrisi dedak padi. Hal ini disebabkan karena kultur khamir dalam proses biofermentasi dapat meningkatkan biomassa mikroba, sehingga kandungan protein kasar dedak padi meningkat (Sutama, 2008). Dilaporkan juga bahwa proses dan produk fermentasi dipengaruhi oleh jenis dan jumlah mikroba yang digunakan, jenis substrat, $\mathrm{pH}$, dan suhu selama proses fermentasi. Biomassa merupakan wujud massa dari hasil proses biologis dari mikroorganisme. Mikroorganisme mampu mengkonversi bahan menjadi protein. Proses fermentasi mempunyai tujuan untuk menghasilkan suatu produk (bahan pakan) yang mempunyai kandungan nutrisi, tekstur, dan nilai biologis yang lebih baik, serta menurunkan zat antinutrisi (Bidura, 2007). Pada saat difermentasi oleh mikroba selulolitik, terjadi kehilangan karbohidrat menjadi panas dan zat makanan lainnya untuk pembentukkan protein mikroba. Menurut Sumarsih et al. (2007), semakin lama waktu penyimpanan bahan pakan saat difermentasi, maka semakin banyak kehilangan bahan kering dan bahan organik bahan, sebaliknya semakin meningkat kandungan protein kasar bahan dan kandungan serat kasar bahan. Dilaporkan juga bahwa semakin lama proses fermentasi atau waktu penyimpanan bahan, maka semakin meningkat kecernaan bahan kering dan bahan organik bahan. Enzim selulase, yaitu selobiohidrolase (C1) yang akan menyerang bagian kristal dari selulosa, endoglukonase $(\mathrm{Cx})$ yang menyerang bagian amorf dari struktur selulosa, dan b-glukosidase yang menguraikan selobiosa menjadi glukosa (Judoamidjojo et al., l989). Mikroba fermentasi mempunyai kemampuan katabolik terhadap komponen organik kompleks, dan diubah menjadi komponen sederhana. Proses tersebut timbul karena adanya aktivitas beberapa enzim yang dihasilkan oleh mikroba.

\section{Protein Kasar dan Serat Kasar}

Kandungan protein kasar (PK) dedak padi kontrol (tidak mengalami fermentasi) adalah $10,93 \%$ berat kering (Tabel 3). Biofermentasi dedak padi dengan kultur khamir Saccharomyces spp kompleks pada level 0,20\% dan 0,40\% dapat meningkatkan kandungan PK dedak padi masing-masing: 19,03\% dan 21,41\% nyata $(\mathrm{P}<0,05)$ lebih tinggi daripada kontrol. Proses fermentasi semi padat dapat meningkatkan protein kasar pakan. Peningkatan protein dikarenakan adanya proses perubahan $\mathrm{N}$ (nitrogen) anorganik dalam bentuk
Tabel 3. Pengaruh penggunaan kultur khamir Saccharomyces spp kompleks sebagai inokulan fermentasi terhadap kandungan zat makanan dan kecernaan zat makanan dedak padi (\% bahan kering).

\begin{tabular}{|c|c|c|c|c|}
\hline \multirow{2}{*}{ Variable } & \multicolumn{3}{|c|}{ Dedak Padi ${ }^{1)}$} & \multirow[b]{2}{*}{ SEM $^{2)}$} \\
\hline & A & B & C & \\
\hline \multicolumn{5}{|l|}{ Komposisi Zat Kimia } \\
\hline Bahan kering (\%) & $88,97 a^{3)}$ & $88,62 a$ & $88,51 a$ & 0.508 \\
\hline Bahan organik (\%) & $89,85 a$ & $90,39 a$ & $90,52 a$ & 0,579 \\
\hline Protein kasar (\%) & $10,93 b$ & $13,01 a$ & $13,27 a$ & 0.305 \\
\hline Serat Kasar (\%) & $15.07 b$ & $17,15 a$ & $17,23 a$ & 0,417 \\
\hline Gross Energi (Kkal/kg) & $3275,37 a$ & $3312,05 a$ & $3326,38 a$ & 75,902 \\
\hline \multicolumn{5}{|l|}{ Koefisien Cerna (\%): } \\
\hline Koefisien cerna bahan kering (\%) & $34,72 b$ & $40,06 a$ & $40,37 a$ & 0,903 \\
\hline Koefisien cerna bahan organik (\%) & $36,39 b$ & $42,71 \mathrm{a}$ & $42,84 a$ & 1,072 \\
\hline Koefisien cerna protein kasar (\%) & $45,84 b$ & $52,95 a$ & $53,01 a$ & 2,152 \\
\hline Koefisien cerna serat kasar (\%) & $20,27 b$ & $24,79 a$ & $24,83 a$ & 1,170 \\
\hline Energi termetabolis (Kkal/kg) & $2017,35 b$ & $2248,36 a$ & $2257,09 a$ & 50,835 \\
\hline
\end{tabular}

Keterangan:

1. Dedak padi tanpa fermentasi sebagai kontrol (A), dedak padi terfermentasi dengan $0,20 \%$ kultur khamir Saccharomyces spp kompleks (B), dan dedak padi terfermentasi dengan 0,40\% kultur khamir Saccharomyces spp kompleks (C).

2. Standart error of the treatment means

3. Nilai dengan huruf yang berbeda pada baris yang sama menunjukkan tidak berbeda nyata $(P>0,05)$

urea maupun amonium sulfat (ZA) oleh khamir menjadi $\mathrm{N}$ organik (protein). Demikian pula kandungan abu, $\mathrm{Ca}$, dan $\mathrm{P}$ pada produk pakan terfermentasi lebih tinggi dari pakan aslinya (Suparjo et al., 2003). Mangisah et al. (2008) melaporkan bahwa proses fermentasi pakan secara signifikan dapat meningkatkan kandungan protein pakan (meningkat 65,41\%).

Kandungan serat kasar (SK) dedak padi kontrol adalah 15,07\% berat kering (Tabel 3). Fermentasi dedak padi dengan kultur khamir Saccharomyces spp kompleks pada level 0,20\% dan 0,40\% dapat meningkatkan kandungan SK dedak padi masingmasing: $13,80 \%$ dan $14,33 \%$ nyata $(\mathrm{P}<0,05)$ lebih tinggi daripada kontrol. Hasil penelitian ini sama dengan hasil penelitian Mahfudz et al. (1996) yang mendapatkan bahwa proses fermentasi dengan menggunakan ragi yang mengandung Rhizopus oligusporus dan $R$. oryzae akan menyederhanakan partikel bahan pakan, sehingga akan meningkatkan nilai gizinya. Fermentasi dedak padi dengan khamir Saccharomyces spp kompleks dapat mengubah protein menjadi asam-asam amino dan secara tidak langsung akan meningkatkan kadar serat kasarnya, karena miselium dari khamir tinggi kandungan serat kasarnya.

\section{Gross Energi}

Kandungan gross energy (GE) dedak padi kontrol adalah 3275,37 kkal/kg bahan (Tabel 3). Fermentasi dedak padi dengan kultur khamir Saccharomyces spp kompleks pada level 0,20\% dan 0,40\% dapat meningkatkan kandungan GE dedak padi namun secara statistic tidak berbeda nyata $(\mathrm{P}>0,05)$ dibandingkan 
dengan kontrol. Hal senada dilaporkan oleh Jaelani et al. (2008), bahwa fermentasi bahan pakan dengan Trichoderma reesei dapat meningkatkan kandungan energi termetabolis, total gula terlarut pakan, dan kandungan protein kasar. Meningkatkan kandungan energi dedak padi terfermentasi tersebut disebabkan karena pembentukan gula yang berasal dari pemecahan serat kasar.

\section{Koefisien Cerna bahan Kering (KCBK) dan Bahan Organik (KCBO)}

Hasil pengamatan menunjukkan koefisien cerna bahan kering dedak padi control adalah $32,72 \%$ berat kering (Tabel 3). Biofermentasi dedak padi dengan kultur khamir Saccharomyces spp kompleks pada level 0,20\% dan 0,40\% dapat meningkatkan KCBK dedak padi masing-masing: $15,38 \%$ dan $16,27 \%$ nyata $(\mathrm{P}<0,05)$ lebih tinggi daripada kontrol. Koefisien cerna bahan organik dedak padi kontrol adalah 36,39\% berat kering (Tabel 3). Biofermentasi dedak padi dengan kultur khamir Saccharomyces spp kompleks pada level 0,20\% dan 0,40\% dapat meningkatkan KCBK dedak padi masingmasing: $17,37 \%$ dan $17,72 \%$ nyata $(\mathrm{P}<0,05)$ lebih tinggi daripada kontrol.

\section{Koefisien Cerna Protein Kasar dan Serat Kasar}

Koefisien cerna protein kasar (KCPK) dedak padi kontrol adalah 45,84\% berat kering (Tabel 3). Biofermentasi dedak padi dengan kultur khamir Saccharomyces spp kompleks pada level 0,20\% dan o,40\% dapat meningkatkan KCPK dedak padi masingmasing: $15,51 \%$ dan $15,64 \%$ nyata $(\mathrm{P}<0,05)$ lebih tinggi daripada kontrol. Koefisien cerna bahan organik dedak padi kontrol adalah 20,27\% berat kering (Tabel 3). Biofermentasi dedak padi dengan kultur khamir Saccharomyces spp kompleks pada level 0,20\% dan o,40\% dapat meningkatkan KCBK dedak padi masingmasing: $22,30 \%$ dan $22,50 \%$ nyata $(\mathrm{P}<0,05)$ lebih tinggi daripada kontrol. Hasil percobaan untuk menentukan kecernaan dedak padi dengan menggunakan metode force feeding menunjukkan bahwa kecernaan BK, BO, PK, dan SK, dedak padi yang mengalami fermentasi dengan menggunakan kultur khamir Saccharomyces spp mengalami peningkatan dibandingkan dengan dedak padi kontrol (Tabel 3). Peningkatan kecernaan bahan kering zat makanan tersebut disebabkan karena mikroba selulolitik dapat menghasilkan enzim amilase dan protease, sehingga keberadaannya dalam proses fermentasi dan di dalam saluran pencernaan akan meningkatkan aktivitas enzim tersebut, dan meningkatkan pula pemecahan zat makanan menjadi bentuk yang lebih sederhana dan mudah diserap oleh saluran pencernaan (Mulyono et al., 2009). Dilaporkan oleh Jaelani et al. (2008), bahwa fermentasi bahan pakan (palm kernel meal) dengan Trichoderma reesei dapat meningkatkan energi termetabolis dan protein kasar bahan pakan.

\section{Energi termetabolis}

Hasil pengamatan dengan menggunakan metode force feeding, dedak padi control mengandung energy termetabolis sebesar 2017,35 kkal/kg bahan (Tabel 3). Biofermentasi dedak padi dengan kultur khamir Saccharomyces spp kompleks pada level 0,20\% dan $0,40 \%$ dapat meningkatkan kandungan energy termetabolis dedak padi masing-masing: $11,45 \%$ dan $11,88 \%$ nyata $(\mathrm{P}<0,05)$ lebih tinggi daripada kontrol. Biofermentasi dedak padi dengan kultur khamir kompleks (khamir Saccharomyces spp.) nyata dapat meningkatkan kecernaan zat makanan dedak padi. Kecernaan protein kasar dan serat kasar serta energi termetabolis dedak padi secara nyata meningkat dengan adanya proses fermentasi. Hal ini menunjukkan bahwa karbohidrat dan komponen serat kasar digunakan oleh khamir untuk pertumbuhannya (protein mikroba). Yi et al. (1996) melaporkan bahwa suplementasi mikroba dalam pakan dapat memperbaiki retensi $\mathrm{N}$ (nitrogen) pada broiler dan meningkatkan kecernaan protein. Dilaporkan juga oleh Chen et al. (2005), bahwa penambahan 0.20\% probiotik kompleks (L.acidophilus and S.cerivisae) dalam ransum basal nyata dapat meningkatkan kecernaan bahan kering pakan. Hal yang sama dilaporkan oleh Bidura et al. (2012) dan Candrawati et al. (2014) bahwa fermentasi pakan dengan menggunakan inokulan khamir (Saccharomyces spp) nyata dapat meningkatkan kecernaan bahan kering, bahan organik, protein kasar, dan serat kasar pakan dibandingkan dengan pakan tanpa fermentasi. Biofermentasi dedak padi dengan kultur khamir Saccharomyces spp dapat melunakkan dan memecah dinding serat kulit ari kacang kedelai, sehingga struktur serat dedak padi menjadi rapuh dan lebih terbuka. Mikroba tersebut bekerja secara bertahap dalam memecah komponen dinding sel. Enzim peroksidase ekstraseluler bekerja secara aktif pada aktivitas lignolisis, sehingga ikatan lignoselulosa putus, dan fraksi lignin terurai menjadi $\mathrm{CO}_{2}$. Biofermentasi dengan menggunakan jasa mikroba dapat meningkatkan kandungan kecernaan zat makanan pakan (Arsyad et al., 2001; Bidura dan Suastina, 2002). Hong et al. (2004) melaporkan, fermentasi pakan dengan menggunakan Aspergilus oryzae nyata meningkatkan kecernaan bahan kering dan protein kasar pakan. Tingginya kandungan non-starch polysaccharides (NSP) dedak padi merupakan faktor pembatas penggunaan dedak padi sebagai pakan dalam ransum unggas. NSP diketahui dapat menyebabkan meningkatnya viscosity saluran pencernaan, menurunnya penyerapan zat makanan dalam saluran pencernaan yang berdampak pada 
menurunnya pertumbuhan ternak unggas (Rhames et al., 2006; Cho et al., 2007). Utama (2011), melaporkan bahwa pemberian khamir $S$. cerevisiae dalam pakan dapat meningkatkan kecernaan protein dan komponen serat kasar, seperti selulosa dan hemiselulosa, karena sudah dirombak dalam bentuk monosakarida sederhana. Bedford dan Classen (1992), menambahkan bahwa fungi sangat efektif dalam mendegradasi senyawa kompleks, seperti $\beta$-glucans dan arabinoxylans. Chen et al. (2005) melaporkan bahwa suplementasi probiotik kompleks dalam ransum nyata dapat meningkatkan kecernaan zat makanan. Menurut Chesson (1994), penggunaan probiotik sebagai feed supplement sangat tergantung pada strain mikroba yang digunakan, level optimal, komposisi ransum, strategi pemberian pakan, bentuk pakan, dan pengaruh interaksi dengan bahan lainnya (feed additive). Banyak penelitian menunjukkan bahwa penambahan kultur probiotik atau enzim dalam pakan yang tinggi kandungan NSPnya secara nyata dapat menurunkan viskositas saluran pencernaan (intestinal viscosity), meningkatkan energi dan protein retensi (Wang et al., 2004; Bidura et al., 2012; Yi et al., l996; Chen et al., 2005). Hong et al. (2004) melaporkan bahwa fermentasi pakan dengan menggunakan kultur Aspergilus oryzae nyata meningkatkan kecernaan bahan kering dan protein kasar pakan, dan meningkatkan kandungan energi termetabolis pakan (Jaelani et al., 2008).

Dari hasil penelitian ini dapat disimpulkan: (1) Biofermentasi dedak padi dengan menggunakan inokulan kultur khamir Saccharomyces spp kompleks yang diisolasi dari ragi tape pada level 0,20-0,40\% dapat meningkatkan kandungan protein kasar dan serat kasar dedak padi dan tidak berpengaruh terhadap kandungan bahan kering, bahan organik, dan kandungan energi (GE) dedak padi. (2) Biofermentasi dedak padi dengan menggunakan inokulan kultur khamir Saccharomyces spp kompleks yang diisolasi dari ragi tape nyata dapat meningkatkan kecernaan bahan kering, bahan organik, protein, dan serat kasar dedak padi, serta dapat meningkatkan kandungan energi termetabolis dedak padi.

\section{UCAPAN TERIMAKASIH}

Pada kesempatan ini penulis mengucapkan terimakasih kepada Rektor Universitas Udayana atas dana yang diberikan melalui dana Penelitian Dosen Muda, sehingga penelitian dan penyusunan tulisan ilmiah ini dapat terlaksana. Ucapan terimakasih penulis sampaikan pula kepada Andi Udin Saransi, SPt., atas bantuannya dalam analisis sampel.

\section{DAFTAR PUSTAKA}

Ariana, I. N. T. dan Bidura I G.N.G. 2001. Bobot dan komposisi fisik karkas ayam broiler yang diberi ransum dengan penambahan serbuk gergaji kayu, ragi tape dan kombinasinya. Majalah Ilmiah Peternakan 4 (1) : 21 - 26

Aryanta, W. R. 1980. Microbiologycal and Biochemical Studies of Ragi and Brem (Rice Wine) of Indonesia. Thesis, Faculty of Graduate School University of The Philippines at Los Banos, Philippine.

Assocciation of Official Analytical Chemists (1994). Official Methods of Analysis. $15^{\text {th }}$ Edition. Associoation of Analytical Chemists, Arlington, Virginia pp. 1230

Barrow, P. A.1992. Probiotic for Chicken. in Probiotics The Scientific Basis (By : R. Fuller). $1^{\text {st }}$ Ed. Chapman and Hall, London.

Bidura, I.G.N.G. 2007. Aplikasi Produk Bioteknologi Pakan ternak. Penerbit Udayana University Press, Denpasar.

Bidura, I.G.N.G., Udayana I.D.G.A., Suasta I M. dan Yadnya T.G.B. 1996. Pengaruh Tingkat Serat Kasar Ransum Terhadap Produksi dan Kadar Kolesterol Telur Ayam. Laporan Penelitian Fakultas Peternakan, Unud., Denpasar.

Bidura, I.G.N.G. dan I.W. Sudiastra. 2002. Suplementasi Ragi Tape dalam Ransum yang Mengandung Kulit Kacang Kedelai terhadap Penampilan dan Distribusi Lemak Tubuh Broiler. Laporan Penelitian Fakultas Peternakan, Unud., Denpasar.

Higa, T. 1994. Effective Microorganism. Technology Serving The World. College Agriculture University of The Ryuksus, Japan.

Kataren, P.P., A.P. Sinurat, D. Zainuddin. T. Purwadarta, dan I.P. Kompiang, 1999. Bungkil inti sawit dan produk fermentasinya sebagai pakan ayam pedaging. Journal Ilmu Ternak dan Veteriner 4 (2): 107 - 112.

Londra, I. M. 2007. Pengaruh Pemberian Pakan Terfermentasi terhadap Pertumbuhan Sapi Bali. Bulletin Teknologi dan Informasi Pertanian, Nomor 16 Th V : 16 - 20

Rasyaf, M. 2002. Bahan Makanan Unggas di Indonesia. Cetakan ke-9 Penerbit Kanisius, Yogyakarta

Steel, R.G.D dan Torrie J.H.. 1989. Prinsip dan Prosedur Statistika. Suatu Pendekatan Biometrik. Edisi Kedua. Alih Bahasa B. Sumantri (IPB). PT. Gramedia, Jakarta.

Tanaka, K., Youn B.S., Santoso U., Ohtani S., and Sakaida M. 1992. Effect of fermented feed products from chub mackerel extract on growth and carcass compotion, hepatic lipogenesis and on contents of various lipid fraction in the liver and the thigh muscle of broiler. Anim. Sci. Technol. 63: $32-37$

Widiyanto, Pangestu E., Surahmanto, Wahyono F., dan Tampoebolon B.I.M. 1994. Teknologi Pengolahan Pucuk Tebu Untuk Merningkatkan Daya Gunanya Sebagai Pakan Ruminansia. Laporan Penelitian, Fapet, Undip, Semarang.

Widiyazid, S. I. K., Parwati I. A., Suyasa N., Guntoro S., Londra I. M., Triagastia I. K., Adnyana Putra A.A.G., dan Widianta G. M.. 2002. Laporan Akhir Pengkajian Sistem Usaha Pertanian Sapi Potong berbasis Ekoregional Lahan Kering. Instalasi Penelitian dan Pengkajian Teknologi Pertanian, Denpasar. 